\title{
Evaluation of cosmetic appearance of herniotomy wound scars in African children: Comparison of tissue glue and subcuticular suturing
}

\author{
A. O. Ademuyiwa, O. A. Sowande, O. Adejuyigbe, U. E. Usang, T. I. B. Bakare, L. J. C. Anyanwu \\ Paediatric Surgery Unit, Department of Surgery, Obafemi Awolowo University Teaching Hospitals' Complex, Ile Ife, Osun State, \\ Nigeria
}

Address for correspondence: Dr. AO Ademuyiwa, Pediatric Surgery Unit, Department of Surgery, College of Medicine, University of Lagos, Idi Araba, Lagos. Nigeria. E-mail: gifthoney@yahoo.com

\section{ABSTRACT}

Aim: To evaluate the cosmetic appearance of herniotomy wound scars closed using either the tissue glue or subcuticular suturing technique. Materials and Methods: Prospective randomised control study; randomisation into tissue glue and suturing groups. Ethical clearance obtained. Cosmetic outcome were based on visual analogue scale by parents and Hollander wound evaluation scale by a Plastic Surgeon blinded to the wound closure method. Results: Fifty one wounds were evaluated, 26 in the tissue glue group and 25 in the suturing group. Parents' evaluation using Visual Analogue scale (VAS) showed that in the suturing group, 17 parents $(68 \%)$ gave a VAS of $8 \mathrm{~cm}$ while six parents $(24 \%)$ gave a score of $7 \mathrm{~cm}$. Two parents $(8 \%)$ gave a score of $9 \mathrm{~cm}$. In the tissue glue group, 22 parents $(84.6 \%)$ scored the scar of their children as 8 or $9 \mathrm{~cm}$ on the VAS while four parents $(15.4 \%)$ gave a score of $7 \mathrm{~cm}$. The median VAS was $8 \mathrm{~cm}$ for both groups with a range of 7 to $9 \mathrm{~cm}$. The Chi- square test showed that the parents preferred tissue glue compared with subcuticular suturing $(\mathrm{X} 2=7.90, \mathrm{P}<0.05)$. The Hollander Wound Evaluation Scale (HWES) used by Plastic Surgeon showed 21 herniotomy wounds (84\%) had a score of 6 in the suturing group while four wounds $(16 \%)$ had a score of 5 . In the tissue glue group, 19 wounds $(73 \%)$ had a score of 6 , six wounds $(23.1 \%)$ had a score of 5 and a patient $(3.8 \%)$ had a score of 4 . The median score is 6 for both groups. There was no statistically significant difference between both groups $\left(X^{2}=1.481, P=\right.$ 0.393). Conclusion: This study has shown that the cosmetic outcome of wound closure using the tissue glue technique and subcuticular suturing technique are similar.

\section{KEY WORDS}

Scars on African skin; tissue glue; wound healing in Africans

\section{INTRODUCTION}

ound closure is an essential part of surgery. In the past, insect tick, flax and animal fibres has been used to close wounds. ${ }^{[1]}$ Technological advancement has made better materials for wound closure possible including absorbable and non absorbable sutures, tapes, zippers and glues. ${ }^{[2,3]}$

The tissue glue (octylcyanoacrylate) has been widely studied and is said to confer some advantages including better cosmetic outcome, faster wound closure time as well as less wound edge related complications. ${ }^{[2,4-6]}$ It also has the added advantage of not requiring removal of 
sutures postoperatively.

In our practice, the subcuticular suturing technique is used to close herniotomy wounds because of its cosmetic outcome as well as the fact that there is no need to remove the sutures following surgery. The use of tissue glue is relatively new in our centre, and a few studies from Africa have investigated the cosmetic outcome of its use. We conducted a prospective randomised study to evaluate the cosmetic outcome of herniotomy wounds using the tissue glue compared with the subcuticular suturing technique.

\section{MATERIAL AND METHODS}

This is a prospective randomised controlled study carried out in the Paediatric Surgery Unit of the Obafemi Awolowo University Teaching Hospitals Complex (OAUTHC) Ile Ife, south west of Nigeria. The surgical procedures for this study were done at the Day Case Surgical Centre of the hospital.

Patients were recruited into the study from those seen at the Paediatric Surgical Outpatient (PSOP) clinic presenting with inguinal hernias. Selection was based on a stratified randomised sampling technique. Patients were stratified into different age groups with similar physiological characteristics and psychosocial development. The different groups included: Infancy, 1 - 5years, 6 - 10 years, and $11-15$ years. Patients falling into each group were thereafter randomly chosen by tossing a coin with 'head' representing the suture group while 'tail' represented the tissue glue group. For patients with bilateral hernia, however, both wounds were grouped into same group because many of the parents preferred that one of the methods should be used for their children and not both methods on the same child.

Fifty two wounds were recruited into the study with 26 each in study and control group 26. The suture used for patients recruited into the suture wound closure group was the 0000 polyglycolic acid (Dexon ${ }^{\circledR}$ ) sutures. The tissue glue 2-Octylcyanoacrylate (Dermabond ${ }^{\circledR}$ manufactured by Ethicon) was obtained from commercial retailers. The study was commenced after due clearance from the Ethics and Research Committee of the Hospital.

Herniotomy through a skin crease incision was performed in all the patients with high ligation of the hernial sac at the internal inguinal ring. ${ }^{[7]}$ The wounds were closed in layers i.e. the external oblique aponeurosis followed by the superficial fascia, with absorbable sutures in both groups. The apposition of the skin was with 2 octylcyanoacrylate in the study group while it was with subcuticular suturing technique in the control group. The application of 2-octylcyanoacrylate was done after the superficial fascia of Camper's has been properly apposed. Toothed dissecting forceps were used to appose the wound about $1 \mathrm{~cm}$ from its medial and lateral limits leaving no space between the apposing wound edges. The tissue glue was then applied carefully on the skin surface making sure that the glue did not seep in between the wound edges. Special precautions as directed by the manufacturers were explained to the parents for strict compliance. Wounds were reviewed for wound edge complications on the $4^{\text {th }}$ and $7^{\text {th }}$ postoperative day as well as $4^{\text {th }}, 8^{\text {th }}$ and $12^{\text {th }}$ weeks postoperatively.

Patients in the subcuticular suturing wound closure group had wound dressings with isotonic saline solution and methylated spirit on the fourth post operative day with gauze dressings while by the seventh day post operation, open dressing with methylated spirit only was performed. Patients in the Dermabond ${ }^{\circledR}$ wound closure group had their wounds inspected with change of gauze only on the fourth postoperative day as the thin film of the tissue glue remained and usually fell off within $7-14$ days. They did not require any dressing solutions.

Assessment of cosmetic appearance based on the Hollander Wound Evaluation Scale and Visual Analogue Scale ${ }^{[2,8,9]}$ was done by the Plastic Surgeon (who was blinded to the method of wound closure) and the parents respectively. The assessment was based on parents' satisfaction with the wound using the Visual Analogue Scale (A sheet of paper on which a 10 - centimetre line is drawn and divided into 10 equal parts from which the parents were asked to assess their level of satisfaction). Zero represented the worst scar the parents could ever imagine while 10 represented the finest scar possible. A Plastic Surgeon assessed the wound using the Hollander Wound Evaluation Scale. These assessments were done at four weeks and 12 weeks post surgery. Also, any sign of allergy to the tissue glue were sought and documented if found.

The data collated was analysed using the Statistical Package for the Social Sciences (SPSS) version13.0.The Chisquare test was used to test the statistical significance of 
the results; a p value of $<0.05$ was taken to be significant.

\section{RESULTS}

There were 52 wounds from 45 patients, seven of whom had bilateral inguinal hernias. However, only 51 wounds were evaluated. A patient in the subcuticular suturing group with surgical site infection was excluded from the study as this could affect the eventual outcome of the scar.

Of the 37 who did not have bilateral hernias, 21 were randomised into the subcuticular suturing group while 16 were in the tissue glue group. There were 26 wounds in the tissue glue method of wound closure and there were 25 wounds in the subcuticular suturing method of wound closure. There was only one female who presented during the study period.

Thirty patients (58.8\%) were in the age group of one to five years while $11(21.6 \%)$ were between six and 10 years of age. There were five patients (9.8\%) each in the infant group and those between 11 and 15 years [Table 1]. There were $20(45.5 \%)$ patients with right inguinoscrotal hernias while 17 (38.6\%) patients had left inguinoscrotal hernias. Seven patients had bilateral hernias representing $15.9 \%$ of the patient population.

There were two cases of erythema around the wound

\begin{tabular}{|c|c|c|c|}
\hline \multirow[t]{2}{*}{ Age of patients } & \multicolumn{2}{|c|}{ Method of wound closure } & \multirow[t]{2}{*}{ Total (\%) } \\
\hline & Dermabond & Suture & \\
\hline $0-12 m$ ths & 3 & 3 & $6(11.5)$ \\
\hline $1-5 y r s$ & 12 & 18 & $30(57.7)$ \\
\hline 6- 10yrs & 8 & 3 & $11(21.2)$ \\
\hline $11-15 y r s$ & 3 & 2 & $5(9.6)$ \\
\hline Total & 26 & 26 & $52(100.0)$ \\
\hline
\end{tabular}

Table 2: Showing the parental visual analogue scale according to wound closure method

\begin{tabular}{lccc}
$\begin{array}{l}\text { Visual } \\
\text { analogue } \\
\text { scale }\end{array}$ & $\begin{array}{c}\text { Dermabond } \\
\text { wound } \\
\text { (parents) }\end{array}$ & $\begin{array}{c}\text { Subcuticular } \\
\text { wound } \\
\text { closure }\end{array}$ & Total \\
\hline 4 & 0 & 1 & 1 \\
7 & 4 & 6 & 10 \\
8 & 11 & 17 & 28 \\
9 & 11 & 2 & 13 \\
Total & 26 & 26 & 52 \\
\hline
\end{tabular}

edges complicating the wound closure (one in tissue glue group and another in the subcuticular suturing group). They resolved spontaneously within a week of surgery. In the subcuticular suturing group, 17 parents (68\%) gave a Visual Analogue Scale (VAS) score of $8 \mathrm{~cm}$ while six parents $(24 \%)$ gave a score of $7 \mathrm{~cm}$. Two parents $(8 \%)$ gave a score of $9 \mathrm{~cm}$ [Figure $1 \mathrm{~A}$ and $2 \mathrm{~A}$ ].

Twenty two parents $(84.6 \%)$ whose children had their wounds closed with octylcyanoacrylate scored the scar of their children [Figure 1B and $2 \mathrm{~B}$ ] as 8 or $9 \mathrm{~cm}$ on the Visual Analogue Scale while 4 parents (15.4\%) gave a score of $7 \mathrm{~cm}$ [Table 2]. The median VAS was $8 \mathrm{~cm}$ for both groups with a range of 7 to $9 \mathrm{~cm}$. The Chi square test showed that the parents preferred tissue glue compared with subcuticular suturing $\left(\mathrm{X}^{2}=7.90, \mathrm{p}<0.05\right)$.

With the use of Hollander Wound Evaluation Scale (HWES) by the Plastic Surgeon, 21 herniotomy wounds (84\%) had a score of 6 in the Subcuticular suturing group while 4 wounds (16\%) had a score of 5 . In the study group closed with 2 - octylcyanoacrylate, 19 wounds $(73 \%)$ had a score of 6 , six wounds (23.1\%) had a score of 5 and a patient (3.8\%) had a score of 4 [Table 3]. The median score was 6 for both groups. There was no statistically significant difference between both groups $\left(\mathrm{X}^{2}=1.481, \mathrm{p}=0.393\right)$.

\section{DISCUSSION}

The first tissue glue was synthesised in 1949. Since that time, there have been attempts to appose wounds using tissue glues with the possible advantage of shorter wound closure time, less wound related complications such as wound infection and wound dehiscence, less postoperative pain and better cosmetic appearance..$^{[2,4]}$ Several studies suggest that the use of tissue glue in wound closure is as effective as the traditional suturing techniques and some studies actually show that it may be superior to suturing. ${ }^{[10]}$ Most of these studies were done

\begin{tabular}{|c|c|c|c|}
\hline $\begin{array}{l}\text { Hollander } \\
\text { Wound } \\
\text { Evaluation } \\
\text { Scale } \\
\text { Score }(0-6)\end{array}$ & $\begin{array}{c}\text { Dermabond } \\
\text { wound } \\
\text { closure }\end{array}$ & $\begin{array}{c}\text { Subcuticular } \\
\text { wound } \\
\text { closure }\end{array}$ & Total \\
\hline 3 & 0 & 1 & 1 \\
\hline & 1 & 0 & 1 \\
\hline 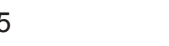 & 6 & 4 & 10 \\
\hline 6 & 19 & 21 & 40 \\
\hline Total & 26 & 26 & 52 \\
\hline
\end{tabular}




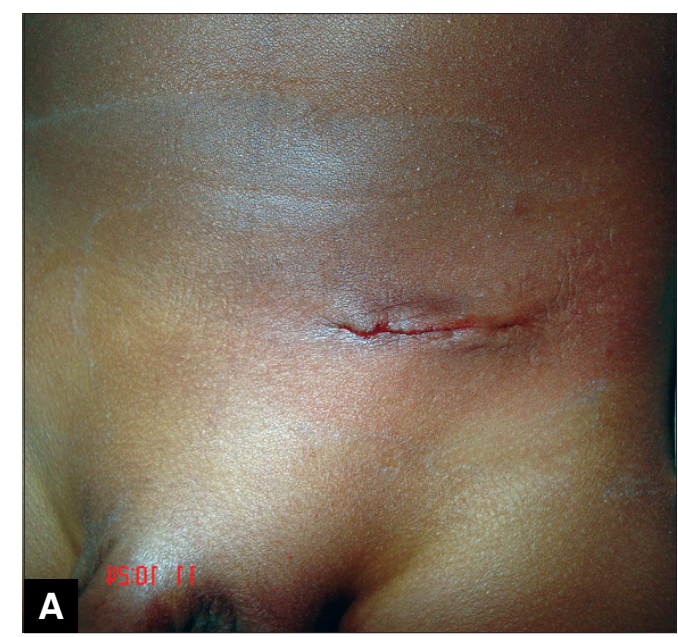

Figure 1A: Perioperative appearance of herniotomy scar (subcuticular suturing technique)



Figure 2A: Appearance of herniotomy scar at 12 weeks (subcuticular suturing technique)

in Western countries and Asia with a few reports from Africa; hence the motivation for this study.

Parents in both groups, tissue glue and subcuticular suturing, were satisfied with the cosmetic outcome of the scars of their children/wards using the Visual Analogue Scale [Figures 1A, 1B, 2A, 2B]. However, it seems parents were more satisfied with use of tissue glue than subcuticular suturing considering that $44 \%$ of the parents in the tissue glue group gave a VAS score of $9 \mathrm{~cm}$ compared with eight per cent of parents whose children's wound were closed using the subcuticular suturing technique. This difference was statistically significant $(P<$ 0.05).

The Hollander Wound Evaluation Scale (HWES) is a validated scale ${ }^{[2,11]}$ and after its use, only one wound was unacceptable (having a score $<5$ ). The one scar which

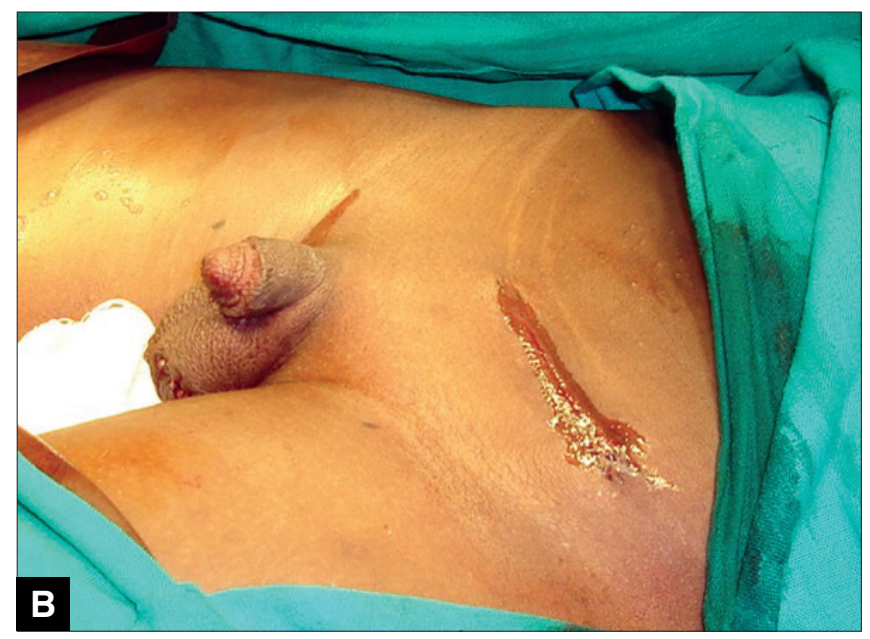

Figure 1B: Perioperative appearance of herniotomy scar (tissue glue technique)

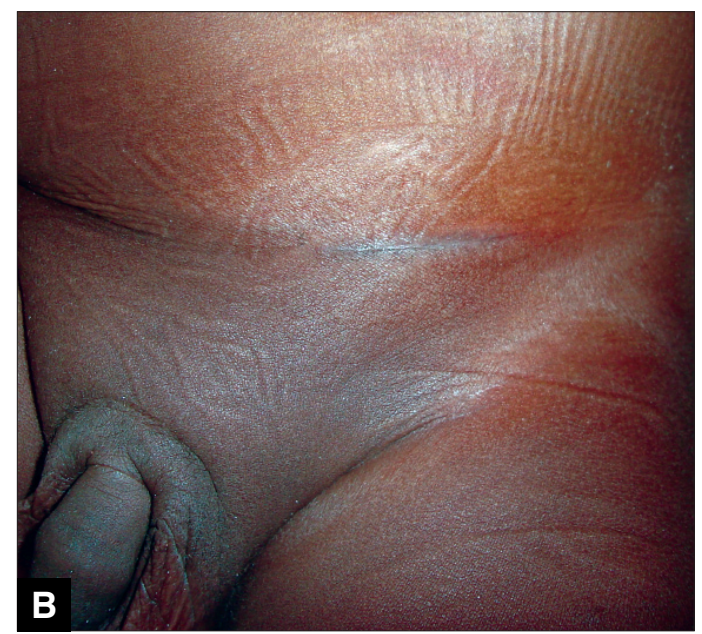

Figure 2B: Appearance of herniotomy scar (tissue glue technique)

was unacceptable was in the tissue glue group and had a score of 4 . With this objective assessment, however, there was no significant difference in cosmetic outcome between the methods of wound closure. This shows that the cosmetic appearance is comparable irrespective of the method of closure of the wounds.

While this study showed that wound closure with the use of Dermabond has the same cosmetic appearance as the time honoured subcuticular suturing technique using the validated HWES, the use of octylacrylate is considered superior to subcuticular suturing with the use of VAS by the parents. The difference in these two scales may be due to the fact that the VAS may be more subjective than the HWES, especially when specific characteristics are not sought to come to a score. Secondly, it is possible that if a larger sample size were used, this difference may become less apparent. 
The satisfaction of parents is a major factor to consider in evaluating the outcome and quality of paediatric surgical practice.

Although this study has shown that the use of tissue glue in African children has at least the same cosmetic appearance when compared with, or may even be superior to the subcuticular suturing technique of wound closure, cost would be a major consideration in the adoption of this method as most of the patients are poor and the cost of closure using tissue glue is about seven times that of closure with suturing technique.

It is to be noted, however, that a limitation of this study is the fact that due to the preference of the parents/ guardians of patients with bilateral inguinal hernias not to have both types of wound closure methods on their children and wards, the individual wounds could not be randomised. In addition, each of such parents had to vote twice. Further studies with larger sample sizes are necessary to confirm or refute some of our observations.

\section{REFERENCES}

1. Daud Galli SK, Constantinides M. Wound closure technique in e-Medicine continuing education 2004. Available from: http:// www.emedicine.com. [last accessed on 2005 Jan 10].

2. Ong CC, Jacobsen AS, Joseph VT. Comparing wound closure using tissue glue versus subcuticular suture for pediatric surgical incisions: A prospective, randomized trial. Pediatr Surg Int
2002;18:553-5.

3. Onuminya JE, Onabowale BO. A prospective evaluation of MedizipTM in Nigeria. W Afr J Med 2002;21:15-8.

4. Keng TM, Bucknall TE. A clinical trial of tissue adhesive (histoacryl) in skin closure of groin wounds. Med J Malaysia 1989;44:122-8.

5. Sinha S, Naik M, Wright V, Timmons J, Campbell AC. A single blind, prospective, randomized trial comparing n-butyl 2-cyanoacrylate tissue adhesive (Indermil) and sutures for skin closure in hand surgery. J Hand Surg Br 2001;26:264-5.

6. Howell JM, Bresnahan KA, Stair TO, Dhindsa HS, Edwards BA. Comparison of effects of suture and cyanoacrylate tissue adhesive on bacterial counts in contaminated lacerations. Antimicrob Agents Chemother 1995;39:559-60.

7. Rescorla FJ. Hernias and umbilicus. In: Oldham KT, Colombani PM, Foglia RP, editors. Surgery of infants and children, scientific principles and practice. Philadelphia, New York: LippincottRaven; 1997. p. 1083-92.

8. Quinn J, Wells G, Sutcliffe T, Jarmuske M, Maw J, Stiell I, et al. A randomized trial comparing octylcyanoacrylate tissue adhesive and sutures in the management of lacerations. JAMA 1997;277:1527-30.

9. Quinn JV, Drzewiecki AE, Stiell IG, Elmslie TJ. Appearance scales to measure the cosmetic outcomes of healed lacerations. Am J Emerg Med 1995;13:229-31.

10. Sinha S, Naik M, Wright V, Timmons J, Campbell AC. A single blind, prospective, randomized trial comparing n-butyl 2cyanoacrylate tissue adhesive (Indermil) and sutures for skin closure in hand surgery. J Hand Surg Br 2001;26:264-5.

11. Hollander JE, Singer AJ, Valetine S, Henry MC. Wound registry: Development and validation. Ann Emerg Med 1995;25:675-85.

Source of Support: Nil, Conflict of Interest: None declared.

\section{Staying in touch with the journal}

1) Table of Contents (TOC) email alert Receive an email alert containing the TOC when a new complete issue of the journal is made available online. To register for TOC alerts go to www.ijpsonline.com

\section{2) RSS feeds}

Really Simple Syndication (RSS) helps you to get alerts on new publication right on your desktop without going to the journal's website. You need a software (e.g. RSSReader, Feed Demon, FeedReader, My Yahoo!, NewsGator and NewzCrawler) to get advantage of this tool. RSS feeds can also be read through FireFox or Microsoft Outlook 2007. Once any of these small (and mostly free) software is installed, add www.ijpsonline.com/rssfeed.asp as one of the feeds. 